thirty years' diary of Thomas Hearne who was a contemporary of Newton, Charles Dickens's personality, leaffall and the blossoming of flowers, and the life and works of men as far apart as Sydney Smith and the scientists Hooker and Airy. In his handling of subjects so diverse the author shows the wide range of his interests and sympathies, and that mastery of lucid statement which seems to belong by birthright to every member of the Darwin family. It is a pleasant volume for a quiet evening by the fireside.

In The New Children, 7 by SHEILA RADICE, we find an excellent appreciation and description of the work of Dr. Maria Montessori, whose name as the founder of a method of child education is now a household word. Put very briefly, the Montessori system aims at allowing the child's mind to develop naturally without being pressed into unnatural forms. It will be remembered that Dr. Montessori first approached the study of normal children through her medical studies of defective children. Having evolved a system for educating defective children, and flnding that, trained in this way, they could compete with their normal brothers and sisters, she was led to the conclusion that there must be something wrong with the system of training the minds of normal children. She has now, we learn, entered upon an investigation of babies, believing that most is to be learnt about children's minds by studying them from birth. Mrs. Radice is a whole-hearted worshipper at the shrine: "What the world has to learn from Dr. Montessori," she declares, is is not only how to treat little children properly-it is a new philosophy of life: Of this philosophy she has as yet given her students but a fraction, from which they are endeapouring to build up the rest for themselves.". When Dr. Montessori visited England last winter, this distinguished member of our profession was entertained at a public dinner, with the President of the Board of Education in the chair, and Mrs. Radice prints an account of the speeches as an appendix to this interesting little book.

MAÚRICE LEVEL, whose Crises, ${ }^{8}$ or short stories of mystery nd horror, have heen admirably translated from the French by ALYS EYRE MACKLIN, was a medical student, and so, as the late $H$. B. Irving writes in a sympathetic introduction, acquired the knowledge of and sympathy with real suffering which gives to some of the most tragic of his tales a true human touch. Among the twenty-six selected from the 700 contes written by $M$. Level for Le Journal, all are enthralling, and some, such as "A Mistake" (in diagnosis) and "Under Chloroform," have a medical setting. Perhaps the nearest approach to them in English is to be found in Miss Louise Heilger's Tabloid Tales, and just as their success led to More Tabloid Tales, so we may hope for a further selection from M. Level's thrilling short stories.

If we were to assert that where three doctors are gathered together there is one fisherman, it would probably be an under-estimate, therefore there will be a large medical audience for Mr. ERIC PARKER's well chosen Angler's Garland 9 Angling has a larger literature in English than any other sport, and much of it reaches a high level, so that the task of selection is not easy. Mr. Parker has judiciously cast his net wide, over some five centuries, and it is curious that his earliest extract, from the Boke of st. Albans (1486), contains implicitly the apology for their devotion which anglers have expressed since with infinite variety in prose or verse. The angler is told that a flsh may, indeed, break him, but " yf he faylle of one he may not faylle of a nother... but yf there be nought in the water." . But even if he do "yet atte the least he hath his holsom walke, and mery at his ease, a swete ayre of the swete fauoure of the meede floures: that makyth hym hungry. He hereth the melodyous armony of -fowles." Also the angler ought to get up early to ftsh, and this "shall cause hym to be holy, and to the heele of his body. ... As the olde englysshe prouerbe sayeth in this wyse, who soo woll ryse erly shall be holy, helthy, and zely." All later apologies for angling are variations on the same theme. The book is well printed, neatly bound, and of convenient size. 7. The Now Children. Talks with Dr. Maria Montessori. By Bheila
Radice. London : Hodder and Stoughton, Itd. 1920. Cr. 8vo, pp. xv 4 Radice. 4s. net.)

Frises. Tales of Mrstery and Forror dome futo English from the dretion by $\mathrm{H}$. B. Irving. Iondon: Erstine MacDonald, Ltd. 1920. (Or. 8vo, pp. 248. 68. not.

An Angler's Garland of Fiolds. Rivers, and Othor Country Contentments. Compiled by Fric Perker. Irondon: P. Allan and Co.
1920. (Fcap. 8vo, pp. 312 . 6e. 6d. netJ

\section{MEDICINE AND THE LAW.}

Address by Lord Justice Atrin.

The Presidential Address before the Medico-Legal Society was delivered on October 19th by Lord Justice ATknN. After expressing his appreciation of the honour done by the society, the President said he proposed to restate, from the point of view of his own judicial experience, the objeat of the society and the close relation existing between the medical profession and the legal profession, with some reference to the practical issues which arise in the course of the administration of justice. Lord Justice Atkin continued: There can be no question, I think, that both branches of the professions-two of what used to be called " the learned professions"-are constantly brought together in the administration of justice, and with the same object - the desire, at any rate, to help to elicit the truth. The result of our being brought together is that there is a large body of medical and surgical knowledge applicable to the elucidation of the issues which are determined in the courts of justice. I assume that that would not be a very incorrect definition of the scope of what is known as medical jurisprudence. I have been very much impressed with the extreme importance to the State that those who take a part in the administration of justice should be really informed upon these particular topics. Doctors are constantly called upon to give evidence in courts of law, and nothing can be more painful than the state of a man who is brought to give evidence upon a particular topic, and to see, as one does sometimes, the man giving evidence to the best of his knowledge on a subject about which he considers he really does know something, and yet to find himself-I don't like to use strong language-turned upside down by a member of a different profession who happens to have a very special knowledge, or has got up a very special knowledge, of the subject. It is not only a matter which is painful to the witness, but might prove sometimes damaging to his career. And in the same way nothing can be, as I often notice, more distreseing than to see a young man, entrusted with a brief for perhaps the first time, haying to fight against the defence of an expert medical witness, who counters him at every blow, and he is quite incapable of making the real point he wants to make. To both branches of the professions knowledge from the professional point of view appears to be of importance. But I think, if one remembers for a moment the occasions on which medico-legal knowledge has been bronght to bear, its value is still more apparent, remembering that the tendency undoubtedly is for the medical evidence to be brought more and more prominently forward in the trial of certain issues. The tendency certainly is to emphasize the effect of physical conditions upon conduct, and rather to express motives in the terms of pathology.

I suppose one might say that, dealing with the criminal law-offences against the person-medical evidence is usually and, in a large percentage of cases, absolutely necessary. That is to say, a medical man is called in to give evidence on one side or the other in all the offences that could be comprised under charges of murder, manslaughter, wounding with felonious intent, or otherwise, all forms of assault, charges of rape and all sexual offences -a very large category, and unfortunately one that tends to fill the calendar of our courts of justice. In dealing with this particular topic one may say this, that the tendency on the part of judges is to regard a medical man who gives evidence, not as an advocate put forward by one side to establish the case, but as an officer of justice there to help the court to elicit the truth, and I think it is of extreme importance that expert witnesses should remember that that is their position. But, at any rate, the judge is entitled, I think, to rely upon the medical man to state fairly the medical facts that bear on the case. And certainly there is nothing more discouraging than to feel that the doctor is anxious to avoid making any admission which, in his opinion, would be likely to be dangerous to the prosecution. Doctors are very fair, and are quite prepared to make any admission that they fairly can make in the course of the case, and I foel satisfied that is the real attitude in which a medical man called in a criminal case ought to approach the matter.

Well, a man may be called on at any moment of his life after he starts practice to take part in any of these charge 
I have mentioned. That which comes prominently to one's mind is charges of murder. From the professional point of view, I cannot help saying that I think a great deal too mach interest is attached to munders and murderers. My experience of them is, that, on the whole, they are not an interesting class of men, and as a whole they deserve very little sympathy. And the ordinary charges of murder that are: made are, in the main, charges in which the facts, and certainly the medical facts, are not interesting at all. It is only occasionally that doubt arises which can be solved only by medical evidence. As a rule, unfortunately, the facts are too plain for dispute, and the only question that arises is, with what motive the man committed the crime. Therefore I am inclined to think, when dealing with questions of medical jurisprudence, that it is possible to attach too much importance to matters which involve questions of life and death-not that the issue itself is not very important, but that from the ordinary modical practitionex's point of view I suppose it is a very small percentage that have to give evidence in such cases. But it is of course encential thet there should bo quelified persons who ane able to give the count; in the most difficult queistions, their amaistance. There:are, howerer, important questions that arise from time to time, and I suppose that any prastitionior, if not brought face to face with on ordinaxy case of nourder, might very often bo callod upon to doal with the suggestion of child murder, and it. is most important, I think, that a modicol man should be able to form $a$ jnsif opinion in eases of that kind. In addition to that, in nearly any murder cane, if a doctor is called ho woald hare: to deal with the question of is sanity, and probably he is the coly perwon who would have: tor deed with it.

Inie mueder case the presectation iscitr the hands of the highest enathonitien and it al ways is considered necessary to call a doctor in ondex to prove that the act alleged against. the person wass the cause of death, however obsions the fact may be; In a hopeless; case the only. passible defence as a rulo is that of insanity, and the counsel for the prisoner is aure to bave to ceoss examiue the doctor as to whiether the socused is sane or insane. 'Therefore the doetor must be prepared: to: deal with it. It is a matter of extreme importance that, the doctor strall be able to maintain his view of the matter. Then there is the question of wounding with intent. Unless one. has somer experience of a criminal court ons would nat appres ciato how often chargess are made of wounding, and the great issue that has to be determined, certainly in indictable offences is whether the wounding is felonions or not, that is $r$ whother it was done with the intention of causing griovous bodily havm. That is an issue which depends veny largely upon the medical evidence. And it alprays appears to me to. be of the greatest importance that the doctor should, first of all, inform himself of the legal definition of grievous bodily harm. I feel satisfied that all members of my profession would not be able to tell straight off what is the legal definition. They should be able also to give a reason for their opinion which would help the jury and the court to determine the question. The kind of question generally asked is, "Did it. require confiderable force?" That, again, is a question which requires a very careful answer, and some knowledge as to what it means. You have to exercise very careful consideration, because the question must be answered, "Yes" or "No," and that may determine whether the man has committed felony or not. The question of wounding is one that a practitioner who is apprehensive of finding himself in a criminal court as a witness should carefully consider. Apropos of wounding, there is a very vexed question as to the state of a man's mind ceused by drunkenness. I suppose most persons who have practised in the criminal courts would agree that a very large percentage of cases of wounding are charges made against men who committed the crime when more or less under the influence of alcohol. I think it is very important to have a pretty fair idea in one's own mind as to the state of consoiousness of a man when he commits an offence of that kind.

Another class of cases, to my mind the most difficult class of cases in which medical men have to appear, is those charges of rape and sexual offences generally. I hore sometimes seen medical mon put in great difficulty in such cases. In all cases of sestual exidence, whethar consent is necessary to be negatived or not, the lady says she was forced and that it happened for the first time. It is essential, from the point of view of the defence, that these statements should be met, beceuse, if the prisoner is able to show that they are untrue, as any such charge depends entirely upon the credibility of the female witness, a great point is made for the defence. That particular issue as to whether or not the girl is a virgin seems to be one which medical men know it is not very easy to predicate with much certainty, and in which doubts upon the matter may reflect very seriously and unjustly upon the complainant, whilst, on the other hand, a great injustice might be imposed upon the defendant. If the medical witness has doubts as to the matter of cerbainty, it is extremely important, to my mind, that he should not go any farther than a man could conaientiously go with complete satisfaction to himself. I think that the medical adviser in a case of that kind is put ocoasionally in very real difficulty. $\mathrm{He}$ is a family dootor, and he finds it is his duty to make a statement which is detrimental to the virtue of one of his patients. It is so great a difficulty that it has occurred to me. that it certeinly would be in the interest of the general practitioner that the court should have recourse, if they can, to their own surgeon-that is; there should be one man in the district, rooognized as an autlsority in medical jurispradence, who would be called as having speeial trnowledge, who would be able to ridithe private praatitioner of a very difficult position. Whether that would be of intercest to the profession, the profeseion themselves could best judge. Another class of cases-I mention it simply becruse of itw importanco-is on with which, I imagine, medical men are constantly brought into contact, cases of abortion. Only a short time ago a paper was read by Dr. Spilsbury; in this room, on the subject, when we heard some horrible details of the torture to which unlappy women are put by the malpractices of criminals, who are sometimes caught and charged. I suppose everyone would agree that, for one case brought into court there are at least a hundred whioh are not. And, in view of the publio dangex anising from the practice, it is a matter in which medical men ought. to be woll informed, and I think they ought. to bo very eareful in reporting cases where they have reason to suspect the fact that such a crime had taken place-I have no doubt they are.

Such are the difficult matters which arise in respect to the criminal law with which medical men meet. A medical man might suddenly, at the outsot of his career, find himiself having to cope with such cases. Then there is-shall $I_{\text {say }}^{\text {sis }}$ on the border line? - the important question of insanity. That raises a very difficult question, upon which, I suppose, there is a good deal of ground for belief that the medical view and the legal view are not completely at one. I cannot imagine a more important function that could be served by this society than, at any rate if it conld be brought abiont that both branches could agree to some formula which would commend itself both to doctors and law yers. There ought to be some change in the formula laid down in Macnaghten's case. I fancy that the chief difficaltoy' is in reference to the medical view, that one ought to take into account, in dealing with criminal responsibility, impaired will power, lack of control. That seems to be the division between the parties, and, of course, there are many matter. to be considered with reference to that. But, certainly, I am inclined to doubt whether in many cases thore is as much difference between the mental operations of person considered sane and a person who would be considered insaue, as there is between the rnental operations of the fraudulent trustee and the loafer who steals a pair of boots. I am inclined to think that the complexity and diversity of the mental operation in either case could be compared together, and, possibly, there would be a greater difference in the case of the latter than in the case of the former. One ought also to remember that, after all, order has to be maintained, and it is no use criticizing the formula in Macnaghten's case unless you can substitute some effective formula in its place which will not have the effect of removing all criminals from a gaol to an esylum. These are matters which should be discussed, and, if practical solution should be arrived at, it would be of very. great valne; and one is essential before you can make the change which would have to be made by legislation. Again, I cannot help thinking that the question of criminal responsibility has been looked at too much in relation to responsibility for murder. Because the formula which 
has to be adopted on criminal responsibility and the effect of it in relieving the criminal from the penal effect of the crime is one that is to be applied as much to the petty theft as to the most serious crime.

In addition to the question of insanity, there is the very important medical side in civil proceedings; and the namber of classes of cases in which medical evidence is given in civil proceedings is very large indeed. I do not wish to deal with the question of divorce. I imagine it is the medical adviser who could in most cases give a better explanation of matrimonial differences than anybody else. One knows that it is the doctor who has to prove the degree of cruelty relied upon, and the courts have to depend very largely upon an honest expression of opinion by the medical man. Then there are the cases which in industrial districts occur more frequently than in other districts, cases under the Workmen's Compensation Acts, where frequently you have to deal with the difficult question as to whether, first of all, the injury arises from the accident at all, whether the patient is suffering from partial incapacity or total incapacity, and if from either, whether that incapacity is permanent incapacity or not. One is certain to meet, as far as applicants are concerned, with these particular medical questions, and the medical man should have his facts well in hand and his medical knowledge : In soldition, there are the similex cases axising out of peceonal injury, and as to how fax the man has been injured by the accident that he is saffering from-questions. as to mervous shock, and whether the efiects of the nervous shock are likely to be permenent; or whether, as counsel for the defendant will al ways suggest, they will disappear when the verdict is given. Again, great injustice may be dore to the parties on one side or the' other if they are not answered accurately, and these are cases in which I think, perhaps more than any other, thexe is apt to be a degree of advocacy on either side.

A great branch of the relations between medicine and law may be covered by what is known as "State medicine," in relation to the ordinaxy duties which doctors have to perform in relation to all depertments of pablio beath. All these topics sem to suggest a i very chose relation between the two professionst While they involvo the knowledge of the doctor on the principal topic with which his skill and attention is requested, they involve equals, the shill of the lawyer, who, in arder to deoide. the naterer and deal satiafactonly with the quostion, has to see that he does not come to a matter with which he is quite unfamiliar. Under these circumstances; ore cannot help thinking that, in the case of either profession, we do not take quite sufflcient pains to secure that; in the ardinary course of training, we are taught, so far as teaching can be given, that which is necessary in respect to medico-legal knowledge. I speak with bated breath of the course of instruction for medical men. I have always boen told, and believe, that it is the moat severe training of any profession: I am quite sure it is very much more severe than the education for a barrister. Whether there is scope in medical training for satisfactory teaching is this matter I do not know. I believe that medical juris prudence is not essential. From what I gather, I am rot sure that in some places where it is taught it has not bieen relegated to the position occupied in school by our French lessons, where the enthusiast may learn if he wishes, but the person who does not wish to learn is not supposed to do anything very wrong if he avoids the course of instruction provided. That is not the case everywhere, but I understand it is in some places, and if, from any sort of discuseion that takes place we can emphasize the extreme importance to the medica man of a knowledge of medical jurisprudence, we shall be doing a valuable work. Whether a course of instruction should be part of the necessary qualification for a medical degree is a different topic. It rather occurred to me it might be only the proper subject for some sort of post-graduate study, if you can get sufficient people to take up the teaching. To my mind, that would be a very valuable addition to what one might call post-graduate instruction, at the Bar. At present there is none. A barrister learns as he goes in practice; the instruction that he gets is in the chambers of the man he reads with. It is very valuable, but it is not systematic instruction. I am glad to see we are making changes in that respect. I. may mention as of great interest to me, as chairman of the Council of Legal Education, that we have secured the assistance of Dr. Spilsbury to give a course of lectures next term on medical jurisprndence, a matter to which $I$ attach great importance, and of which I believe the young barristers will be delighted to take advantage.

We have talked about medical knowledge, medical jurisprudence for doctors and lawyers, but does it not seem to follow that, in addition to the actual medical topics on the one side and the legal matters on the other, an interchange of instruction might take place betweeu the two professions? It is very difficult, to my mind, to learn medical jurisprudence adequately from the medical side, without having a reasonably clear knowledge of what the law is upon the particular matters. You wish to know how medical facts are appropriate to the particular legal issue. So far as the law is concerned, it is better taught by lawyers than by any one else, as I imagine medical matters botter come from medical men than from non-medical men. And if some of our. young men at the Bar should receive medical instruction, it might be of advantage to doctors if we could exchange, and that barristers ard law yers should give lectures on the criminal law, so far as it is apmopriste to the matters that come within the scope of medical men. These are the matters which have occurred to me to put forward as suggestions to this society. I appreciate how very close are the mutual relations of the two professions, and if there is anything we can do to improve and assist medical men on the one hand, and lawyers on the other, in matters connected with tho administration of justice, I shall be entirely astisfied.

Discussion:

In the discussion that followed, Earl Russers stggested that in civil cases it would be a little too much to expeet that a doctor called as an adrocate for one side, or the Other should be an offlcer of the court. With regard to the rule in Macnaghten's case on the question of insanity, medical man looked on this as a scientific quostion and stated his conclusion from the point of view of science. But the member of the Bar, who reached the jury and the general criminal pablic, said: "I have some eriminals trere; what am I to do with them ?" The speaker thought that this was really where the difference lay between the medical and the legal standpoirts. No one desired to infilet purwishment on a person who was not responsible for his actions, but still they wished to do something for him in an effective way; there was no objection to sending him to a criminal asylum provided he was kept there. Earl Russell agreed that it would be a great advantage to both professions if each acquired some working knowledge of the other'in cases in which they overlapped or touched. He therefore welcomed the lectures to be given by Dr. Spilsbary to Bar students, and thought that if, on the other hand, medical men were given some simple instructhon in the elements of criminal law, this would help them to appreciate the points to be met. In that way both professions would come closer together when they found themselves trying, often at cross purposes; to arrive at the truth.

Sir ROBERT ARMSTRONG-JONES expressed his high apprectation of the President's address. On the question of responsibility he said there ought to be a very definite rapprochement between the medical and the legal sides. The difflculty, to his mind, was that the legal man was an advocate for his case and the medical man an advocate for truth. Dr. F. G. CRUICKSHANK related an adventure he had some years ago when assistant medical offeer in an asylum. This ended with a legal argument, in which he got the better of a homicidal patient.

Lord Justice ATKIN, in reply, said he had not meant to suggest that the doctor should hold a different position from that of any other expert witness. He agreed that it would be a counsel of perfection to suggest that in civil cases the doctor should regard himself as there merely to assist the court, though he thought it should be so in criminal cases. He was reluctant to accept Sir Robert Armstrong-Jones's antithesis about barristers and doctors : both, he fancied, were the advocates of truth. The matter of criminal responsibility was one of the very greatest importance, and it would be well for them in the first place to lay the foundation of some satisfactory formula, some mode of agreement between both professions.

SIR JOHA MOCALL, for ten years Agent-Gemeral in London for Tasmania, who died in June, 1919, left property valued at $£ 15,307$, of which $£ 12,593$ is in Tasmania and $\$ 8,714$ in this country. 